\title{
OPTIMIZING THE PROCESS CONDITIONS IN SCIENCE AND ENGINEERING FOR IMPROVEMENT OF PRODUCT ENGINEERING
}

\author{
Eny Kusrini ${ }^{1,2 *}$ \\ ${ }^{1}$ Department of Chemical Engineering, Faculty of Engineering, Universitas Indonesia, Kampus UI \\ Depok, Depok 16424, Indonesia \\ ${ }^{2}$ Tropical Renewable Energy Center, Faculty of Engineering Universitas Indonesia, Kampus UI \\ Depok, Depok 16424, Indonesia
}

Finding the novelty in and developing new science and engineering applications in the world is very important and interesting. Overall, process and product engineering aims to improve and increase the effectiveness of the engineering process in order to achieve the optimum conditions. However, engineering and environmental applications still contain various limitations such as high energy demand, catalyst costs, and less reuse or regeneration of adsorbents and catalysts. These challenges have led to the exploration of cheaper precursors, the regeneration of adsorbents or catalysts, mechanisms reactions, and overall optimization of the engineering process. Moreover, multifunctional and advanced materials could be promising as materials for further applications. To the best of our knowledge, investigation and exploration of the precursors, methods, design, instruments, product, and/or manufacturing is required for the future as they facilitate and integrate with each other. The adsorption process is a simple and important method for many applications within the environment and industries to deal with the removal of heavy metals, pollutants, and odor from wastewater, and to tackle polluted air. Clean energy sources and global warming have been major issues and challenges for many years, including a reduction of $\mathrm{CO}_{2}$. Much attention has been paid to the key issue of developing alternative uses for by-products (waste) in addressing the sustainability of this resource. In particular, the utilization of any by-product (waste) as a useful product should be considered as a source of economic, eco-friendly, high-efficiency, and renewable materials, and should follow at least one rule, such as the "polluter pays" principle. This is expected to pave the way for the attainment of advanced applications. All of the findings of this research are effective and may be used to enable the further development of environmental applications for the removal of a diverse range of pollutants, diminish hazardous pollutants, and facilitate the minimization method for the management of waste. On the other hand, to improve the production of renewable energy and further applications, the overall process also needs to be considered, including the temperature, time, feedstock composition, catalyst, and arrangement of the design.

To address the above problems, the $2^{\text {nd }}$ International Tropical Renewable Energy Conference (iTREC) 2017 was held on October 3-4, 2017 at the Courtyard by Marriott Bali Nusa Dua Resort, Bali, Indonesia. The $2^{\text {nd }}$ i-TREC 2017 was proudly organized by the Tropical Renewable Energy Center, Faculty of Engineering, Universitas Indonesia. The main theme of the $2^{\text {nd }}$ i-TREC 2017 was "Towards Tropical Renewable Energy Innovation and Technology Integration." The 168 presented papers came from various countries, such as Australia, Brunei Darussalam, Brazil, France, Indonesia, Japan, and Malaysia. The $2^{\text {nd }}$ i-TREC 2017 covered

\footnotetext{
*Corresponding author's email: ekusrini@che.ui.ac.id, Tel: +62-21-7863516 ext. 204, Fax: +62-21-7863515 Permalink/DOI: https://doi.org/10.14716/ijtech.v9i2.1930
} 
three symposia, namely Renewable Energy System and Regulation, Biomass and Biotechnology, and Multifunctional and Advanced Materials for Renewable Energy Applications. From a total of 168 papers from the three symposia, we selected 22 for publication in IJTech. The papers are from a range of fields, as follows: architecture (1), chemical engineering (9), civil engineering (1), electrical engineering (1), mechanical engineering (7), and metallurgical and materials engineering (3). All of the 22 selected papers from the three symposia are summarized below.

The first paper, written by F.N. Ani, N.H. Said, and M.F.M. Said, investigated the continuous flow transesterification of Waste Cooking Oil (WCO) by microwave irradiation for biodiesel production using calcium oxide $(\mathrm{CaO})$ as a heterogeneous catalyst, calcined from cockle shells. The catalyst was packed inside a plastic perforated container mounted on a stirrer shaft and inserted in a reactor. The thermocouple inside the reactor was connected to a temperature controller and microwave power input to maintain the temperature. Response surface methodology (RSM) was employed to study the relationships between power input, stirrer speed, and Liquid Hourly Space Velocity (LHSV) on the WCOME conversion at a fixed molar ratio of methanol to oil of 9 and a reaction temperature set at $65^{\circ} \mathrm{C}$. The transesterification of the WCO was produced at $72.5 \%$ maximum WCOME conversion at an optimum power input of $445 \mathrm{~W}$, stirrer speed of $380 \mathrm{rpm}$, and LHSV of $71.5 \mathrm{~h}^{-1}$. The energy consumption in a steady state condition was $0.594 \mathrm{kWh}$ for the production of 1 litre of WCOME, since this heterogeneous catalyst is much faster than conventional heating.

The second paper is written by H. Wahyudi, M.P. Pinem, I. Rosyadi, and K. Chu. It evaluates the three-dimensional Eulerian Multi-Fluid Model (MFM) of biomass gasification in full-loop Circulating Fluidized Beds (CFBs). They found that a model that considers all inter-solid phase heat-transfer mechanisms provides better predictions in terms of synthetic gas (syngas) compositions than both a model that considers direct solid-solid conduction through contact area only and a model with no solid-solid heat-transfer mechanisms. From this, hydrodynamics and heat and mass transfer inside this complex system are analyzed, which is useful for the promotion of better design and optimization of biomass gasification in CFBs.

The third paper, written by N.H. Said, F.N. Ani, and M.F.M. Said, evaluated the effect of using biodiesel from WCO Methyl Ester (WCOME) blends on diesel engine emissions and performance. WCOME blends were tested in a single-cylinder Direct Injection (DI) diesel engine at a constant speed of $2500 \mathrm{rpm}$ and with five loads. The authors found that the use of Palm Oil Mill Effluent (POME) and WCOME blends led to increments in Brake Specific Fuel Consumption (BSFC) of up to 5.9\% and reductions in Brake Thermal Efficiency (BTE) of up to 29.3\% compared to Petron Diesel Max (PDM). These biodiesel blends also increased nitrogen oxide emissions and decreased carbon dioxide, carbon monoxide, and hydrocarbon emissions for all engine loads at a constant speed of $2500 \mathrm{rpm}$. The experimental testing of the cylinder peak pressure demonstrated a significant increase with the increase of engine load for the four test fuels.

The fourth paper, written by F.X.T.B. Samodra, evaluated the optimization of the room acoustic criteria of different building models as building systems integrated with loudspeakers. Ecotect Analysis and additional audio programming were used to determine the overall process by simulating all potential variables. They found that 5 meters is the recommended minimum distance of column-loudspeaker placement for mezzanine floors. With the same loudspeaker power and frequency specifications, the vertical structure, as the armature of electroacoustic orientation, and the interior materials are the most critical variables in determining optimization of reverberation time. 
The fifth paper, written by M. Günther, investigated the specific challenges brought to the JavaBali grid system by a $100 \%$ renewable energy scenario. This objective was achieved by designing power generation time series such that they matched a given load time series. An important challenge for a $100 \%$ renewable energy supply is its very high dependency on solar energy, which generates an enormous primary power generation fluctuation on both a daily and an annual timescale. In particular, seasonal fluctuations are accompanied by high storage demand, which is the greatest challenge involved in a 100\% renewable energy supply. However, there are strategies that may be used to considerably reduce the storage demand: the installed photovoltaic (PV) capacity can be increased, bioenergy can be used for seasonal balancing, and special long-term storage can be added.

The sixth paper, written by D.F. Wijayanti, N. Suwartha, and C.R. Priadi, investigated the performance of a dry Anaerobic Digestion (AD) food waste reactor after the addition of Fat, Oil, and Grease (FOG) waste. The research was conducted using a Semi-Continuous Stirred Tank Reactor (SCSTR) with an active volume of $400 \mathrm{~L}$, operated at an average temperature of $27.8 \pm 1.07^{\circ} \mathrm{C}$, using an Organic Loading Rate (OLR) of approximately $10 \mathrm{~kg}$ volatile solids $(\mathrm{VS}) / \mathrm{m}^{3}$, with a constant mixing intensity of $30 \mathrm{rpm}$. They found that there was a significant difference between the input of food waste substrate with and without the addition of FOG $(\mathrm{p}<0.05)$. The average reduction of VS and Chemical Oxygen Demand (COD) removal in the substrate input with FOG addition was higher than without the addition. The mean percentages of COD removal and VS reduction in the substrate input with FOG addition were $63.3 \pm 2.71 \%$ and $89.30 \pm 1.55 \%$, whereas those for substrate input without FOG addition were $59.45 \pm 4 \%$ and $77.65 \pm 1.46 \%$, respectively. The study concludes that the use of FOG as a co-substrate in a dry $\mathrm{AD}$ food waste reactor is not only beneficial in reducing FOG waste generation, it also has a significant impact on reducing COD and VS, which can enhance potential biogas yield.

The seventh paper, written by Nasruddin, S. Nasution, N. Aisyah, A. Surachman, and A.S. Wibowo, evaluated a geothermal power plant binary cycle system model that was tested by using waste brine at a temperature of $180^{\circ} \mathrm{C}$ at well pad 4 of the Dieng geothermal power plant. In the optimization procedure, total exergy destruction and total annual cost were chosen as the objective functions. Optimization is achieved by using a multi-objective genetic algorithm. Based on the simulation, it is known that the exergy efficiency and economic value of the optimal binary cycle of the geothermal power plant system has optimum conditions at an evaporation temperature of $163.3^{\circ} \mathrm{C}$, a brine temperature in the preheater outlet of $130^{\circ} \mathrm{C}$, and a water cooling temperature at the condenser outlet of $35.4^{\circ} \mathrm{C}$. The working fluid pressure at the pump outlet is $3859 \mathrm{kPa}$, with the composition of the working fluid mixture being $86 \% \mathrm{R} 601$ and 14\% R744, resulting in a turbine power of $119.8 \mathrm{~kW}$, total exergy destruction of $742.4 \mathrm{~kW}$, and a total annual cost of 36,723 US dollars. They found that by setting the above operating conditions, the system can achieve optimum efficiency, as indicated by the minimum values for both exergy destruction and total annual cost.

The eighth paper, written by E. Kusrini, C.S. Utami, A. Usman, Nasruddin, and K.A. Tito, compared the graphite/ $\mathrm{CeO}_{2}$ composites and cerium oxide (ceria, $\mathrm{CeO}_{2}$ ) for $\mathrm{CO}_{2}$ capture. The graphite $/ \mathrm{CeO}_{2}$ composites at different weights of $\mathrm{Ce}\left(\mathrm{NO}_{3}\right)_{3} .6 \mathrm{H}_{2} \mathrm{O}(0.5,1$, and $2 \mathrm{~g})$, namely G0.5, G1, and G2, respectively, were derived from isothermal adsorption data at various pressures $(\mathrm{P})$ of 3, 5, 8, 15 and 20 bar, and temperatures $(\mathrm{T})$ of 303, 308, and $318 \mathrm{~K}$. By varying the two parameters ( $\mathrm{P}$ and $\mathrm{T}$ ), the maximum adsorption capacities of $\mathrm{CO}_{2}$ at $303 \mathrm{~K}$ and 20 bar were found to be $0.0713,0.0316,0.1574,0.0987,0.1137$ and $0.0964 \mathrm{~kg} / \mathrm{kg}$, respectively, for graphite waste before modification (GBM), activated graphite waste (GA), G0.5, G1, G2 and $\mathrm{CeO}_{2}$. The highest adsorption capacity of $\mathrm{CO}_{2}$ was found in the $\mathrm{G} 0.5$ composite. The adsorption performance of $\mathrm{CO}_{2}$ using ceria was almost similar to the $\mathrm{G} 1$ composite. We found that $\mathrm{CO}_{2}$ adsorption capacity decreases with an increasing temperature from 303 to $318 \mathrm{~K}$. They reported 
that new sorbents of graphite waste/CeO $\mathrm{C}_{2}$ composites and ceria are stable and selective $\mathrm{CO}_{2}$ sorbents that can be effectively applied for $\mathrm{CO}_{2}$ capture. The adsorption capacity of $\mathrm{CO}_{2}$ depends significantly on the active site and chemical modifier of the sorbents.

The ninth paper, written by R.E. Respati, M.H. Kusuma, and N. Putra, designed a cascade solar desalination system with integrated thermosyphons and to establish its ability to produce fresh water. They found that the cascade solar desalination system with integrated thermosyphons was able to produce an average amount of fresh water of $38.6 \mathrm{~mL} / \mathrm{h}$, with an average daily thermal efficiency of $18.78 \%$. On the other hand, the same system without the thermosyphons produced on average $9.9 \mathrm{~mL} / \mathrm{h}$ of fresh water, with an average daily thermal efficiency of $8 \%$. These results indicated that the use of thermosyphons in the cascade solar desalination system can increase freshwater productivity by up to 3.89 times and increase the thermal efficiency of the system by up to 2.35 times.

The tenth paper, written by M.T. Adiwibowo, M. Ibadurrohman, and Slamet, described the synthesis of $\mathrm{ZnO}$ nanoparticles by a solochemical method using zinc chloride as the precursor in a sodium hydroxide solution with $\mathrm{ZnCl}_{2}: \mathrm{NaOH}$ ratios of $1: 2$ and 1:3. Calcined $\mathrm{ZnO}$ underwent a drying process at $120^{\circ} \mathrm{C}$, followed by calcination at $500^{\circ} \mathrm{C}$, while uncalcined $\mathrm{ZnO}$ underwent the drying process only. The photoactivity of synthesized $\mathrm{ZnO}$ was evaluated through methylene blue degradation. The nanofluidic stability in the presence of a Palm OilBased Primary Alkyl Sulphate (palmPAS) surfactant was investigated using a spectrophotometer UV-vis with varied PalmPAS concentrations. All of the synthesized $\mathrm{ZnO}$ nanoparticles exhibited good photoactivity under UV light irradiation due, to some extent, to their good crystallinity. The calcined $\mathrm{ZnO}$ obtained using the $\mathrm{ZnCl}_{2}: \mathrm{NaOH}$ ratio of 1:3 offered the best photocatalytic performance compared to its $\mathrm{ZnO}$ counterparts. It was also found that the nanofluids of uncalcined $\mathrm{ZnO}$ from the $\mathrm{ZnCl}_{2}: \mathrm{NaOH}$ ratio of 1:3, at a $\mathrm{ZnO}$ :palmPAS ratio of 1:9, offered the best stability.

The eleventh paper, written by J. Muliawan and S. Astutiningsih, investigated the attempted utilization of phosphate sludge (PS) by mixing it in kaolin in the preparation of ceramic bricks. A series of experiments showed that mixtures containing $25-50$ mass \% PS sintered at $1200^{\circ} \mathrm{C}$ attained the highest compressive strength of $>25 \mathrm{MPa}$. X-ray diffractions (XRD) showed that the presence of PS hindered the formation of mullite, the phase that contributes to strength in the $\mathrm{Al}_{2} \mathrm{O}_{3}-\mathrm{SiO}_{2}$ kaolin system. In the mixture of $1: 1$ kaolin:PS fired at $1200^{\circ} \mathrm{C}$, cristobalite was formed, instead of mullite.

The twelveth paper, written by A. Maresya, D.N. Putri, R. Arbianti and H. Hermansyah, investigated the optimum value of lipase activity produced by the cultures of Pseudomonas aeruginosa using Palm Oil Mill Effluent (POME) as the substrate through the submerged fermentation method and to obtain the dry extract of lipase. They found that the optimum value of the lipase activity unit $(1.327 \mathrm{U} / \mathrm{mL})$ was gained when $3 \%(\mathrm{v} / \mathrm{v})$ of inoculum, $4 \mathrm{mM}$ of $\mathrm{Ca}^{2+}$ ion, $0.4 \%(\mathrm{v} / \mathrm{v})$ of olive oil, $0.9 \%(\mathrm{~m} / \mathrm{v})$ of peptone, and $0.9 \%$ of Tween 80 were added into the medium. Subsequently, $15.643 \mathrm{~g}$ of dry extract lipase was obtained from $500 \mathrm{~mL}$ of cell-free supernatant. The dry extracelluler lipase obtained had an activity unit of $28.5 \mathrm{U} / \mathrm{g}$, with a specific activity of $2.417 \mathrm{U} / \mathrm{g}$ proteins. The utilization of POME as an alternative medium would result in a considerable reduction in the cost of lipase production

The thirteenth paper, written by K. Mulia, D. Adam, I. Zahrina, and E.A. Krisanti, evaluated the performance of Natural Deep Eutectic Solvents (NADES), with each one consisting of betaine as the hydrogen bonding acceptor and a polyalcohol as the hydrogen bonding donor, to extract palmitic acid from palm oil. They found that in NADES with a similar polarity to that of betaine, the extraction yields reduced with increasing viscosity of the NADES. The highest extraction yield of $60 \%(\mathrm{w} / \mathrm{w})$, corresponding to a distribution coefficient value of 0.75 , was 
obtained by using NADES consisting of betaine and 1,2-butanediol. The extraction yield and distribution coefficient values indicated the potential of NADES, prepared by friendly compounds of betaine and polyalcohols, as alternative green solvents in the solvent extraction process when separating free fatty acids from palm oil.

The fourteenth paper, written by H. Judawisastra, R.D.R. Sitohang, D.I. Taufiq, and Mardiyati, developed starch-based biofilms made from jicama. The films were fabricated by using the solution casting method, with varying contents of water (67-93 wt.\%) and sodium hydroxide $(0.3-0.7 \mathrm{~g})$. They found that $\mathrm{NaOH}$ improved the film formability but that it also induced fragility. The highest tensile strength and stiffness of $11.5 \mathrm{MPa}$ and $0.98 \mathrm{GPa}$, respectively were achieved from the film prepared with $93 \mathrm{wt} \%$ water. These values are comparable to low density polyethylene (LDPE) but with a lower ductility.

The fifteenth paper, written by Praswasti P.D.K. Wulan and Y.D. Lestari, investigated the effect of Oxidative Heat Treatment (OHT) on the preparation of Stainless Steel (SS) in the formation of Carbon Nanotube (CNT). Stainless steel (SS) was prepared with chloride acid, $\mathrm{HCl}(37.8 \%)$, and $\mathrm{OHT}$ at $850^{\circ} \mathrm{C}$ for 30 minutes. The result of using acetylene for 20 minutes in respect of the three variations produced carbon loss of over $90 \%$. This is due to an increase in the $\mathrm{Cr}$ percentage, which inhibits the formation of the catalyst's nanoparticles. With the help of ferrocene foil substrate, plate, and wire mesh, the amounts of CNT produced were 0.0573 gram, 0.0701 gram and 0.1246 gram, along with a reduction in carbon loss to $30 \%$. The use of SS 316 substrate with a lower $\mathrm{Cr}$ content and increasing the synthesis time to 60 minutes yielded a mass of 0.6325 gram and carbon loss of $2.76 \%$. By using camphor for 60 minutes, the identification resulted in an increase of CNT mass in SS 304 of 0.831 for foil, 1.856 for plate, and 2.6305 for wire mesh. Based on this experiment, SS types 304 and 316, along with the OHT preparation method, can easily be used as an effective substrate to produce CNT.

The sixteenth paper, written by E. Susanto, M.I. Alhamid, Nasruddin, and Budihardjo, investigated the effect of regulated thermostat settings on household refrigerator energy consumption. They found that household refrigerator energy consumption increases with higher thermostat settings. An increase in energy consumption of $0.175 \mathrm{kWh} /$ day was obtained when the thermostat setting was increased from point 1 to point 3 . Whereas, a slight increase in energy consumption of $0.016 \mathrm{kWh} /$ day when this setting was increased from point 3 to point 4 . Increases in energy consumption range from $17.10 \%$ to $18.65 \%$, depending on the thermostat setting. With the thermostat setting change from point 3 to point 4 , there was no significant change in energy consumption or drop in temperature, so it can be concluded that setting the thermostat to point 3 is sufficient to keep food fresh. While even testing the energy consumption of the same refrigerator is not necessarily the same result.

The seventeenth paper, written by N. Sofyan, Muhammad, A. Ridhova, A.H. Yuwono, and A. Udhiarto, prepared synthesized carbon from the precursors of table sugar and sucrose through a chemical process, i.e., the dehydration of the precursors with sulfate acid followed by a pyrolysis process, and used this as a Pt-less counter electrode in a DSSC device. They found that the precursors of table sugar without the addition of a metal catalyst and with initial heat treatment at $300^{\circ} \mathrm{C}$ for 1 hour, and of sucrose with a catalyst could produce carbon with a particle size of around 600-900 $\mathrm{nm}$. The current-voltage (I-V) characteristic curve of the DSSC device assembled using carbon produced from sucrose as a counter electrode resulted in a power conversion efficiency (PCE) of only $0.041 \%$, whereas the DSSC device assembled using carbon produced from table sugar as a counter electrode exhibited a good performance with a PCE of $3.239 \%$, almost equivalent to that of platinum paste with a PCE of $4.024 \%$. This result is promising in terms of its implication for using a cheap source of carbon as a Pt-less counter electrode. 
The eighteenth paper, written by Setiadi and N. Hidayah, investigated the optimum amount of papain enzyme used in the hydrolysis reaction to achieve the most stable $\mathrm{O} / \mathrm{W}$ lecithin emulsion type. They found that the breaking of a single fatty acid chain from the structure of lecithin can be demonstrated by Fourier-Transform Infrared spectroscopy (FTIR) instrumentation. The emulsion stability for the O/W type was achieved in modified-lecithin using a $4 \%$ papain enzyme dosage, with a stability duration of up to 31 hours. The lowest acid number was achieved in modified-lecithin using a $2 \%$ papain enzyme dosage with a value of 10.40 . The lowest surface tension was obtained in modified lecithin using a $2 \%$ papain enzyme dosage with a surface tension value of $48.68 \mathrm{dyne} / \mathrm{cm}$. The zeta potential of the modified lecithin using a $2 \%$ papain enzyme had a value of $-94.8 \mathrm{mV}$. They concluded that the enzymatic hydrolysis of lecithin using a papain enzyme is clearly able to enhance the emulsifier properties of the lecithin produced.

The nineteenth paper, written by F.R. Gibran, A. Surjosatyo, A.A. Hermawan, H. Dafiqurrohman, M.B. Anggriawan, N.R. Yusuf, and S. Maarif, investigated the optimum Air Ratio (AR) between the secondary and primary air supplies, and the optimum height ( $\mathrm{Z}$ ) of a secondary air intake to produce syngas with the highest energy and lowest tar content. The optimum AR of the secondary air stage gasifier was $80 \%$ at $\mathrm{Z}=38 \mathrm{~cm}$ and a flaming pyrolysis with the longest duration of 400 seconds, which indicated that this condition had the lowest tar content; meanwhile, at $\mathrm{Z}=50 \mathrm{~cm}$, gas with the highest energy $(734.64 \mathrm{~kJ})$ and a pyrolysis zone temperature range of between 500 and $800^{\circ} \mathrm{C}$ was obtained.

The twentieth paper, written by A. Hidayat, N.I.F. Mukti, B. Handoko, and B. Sutrisno, developed natural zeolite impregnated with potassium nitrate $\left(\mathrm{KNO}_{3}\right)$ as a heterogeneous catalyst for the transesterification of Rice Bran Oil (RBO) in order to produce Fatty Acid Methyl Ester (FAME). They found that the highest biodiesel yield (83.2\%) was obtained at a ratio of 1:12 RBO to methanol mole, an amount of modified natural zeolite catalyst of $10 \mathrm{wt} . \%$ of $\mathrm{RBO}$, and a reaction temperature of $67.5^{\circ} \mathrm{C}$. This indicated that potassium supported on natural zeolite (the K/NZ catalyst) could be used as a catalyst for the transesterification of RBO. The K/NZ catalyst could be reused up to 3 times for esterification reactions; however, this reduced the biodiesel yield to $52.3 \%$.

The twenty-first paper, written by Y. Muharam, E. Kusrini, N. Saubryani, and M. Ulfa, investigated the simulation of an adsorbed natural gas storage tank to predict the filling time, filling capacity, and storage efficiency. A high-capacity HKUST-1-type metal-organic framework was used as an adsorbent. The cylindrical tank was $1.09 \mathrm{~m}$ in length with a radius of $0.15 \mathrm{~m}$, and was equipped with an inlet hole for gas inflow. They found the temperature increase in the tank due to adsorption heat to be very significant. This affected the adsorption ability of the bed inside the tank, meaning the storage efficiency was consequently low. For an inlet gas flow rate of $50 \mathrm{~L} / \mathrm{min}$, the storage efficiency was $38 \%$ and increased to only $47 \%$ at 5 $\mathrm{L} / \mathrm{min}$. The corresponding filling capacities for the two flow rates were not very different, i.e., $89 \mathrm{~V}(\mathrm{STP}) / \mathrm{V}$ and $109 \mathrm{~V}(\mathrm{STP}) / \mathrm{V}$. However, the difference in the filling times was extremely significant, being found to be $16 \mathrm{~min}$ at $50 \mathrm{~L} / \mathrm{min}$ and $255 \mathrm{~min}$ at $5 \mathrm{~L} / \mathrm{min}$.

The twenty-second paper, written by S. Muhammaddiyah, A. Winarta, and N. Putra, studied the effectiveness and heat recovery values of heat pipe heat exchangers (HPHEs) in Heating Ventilating Air Conditioning (HVAC) ducting systems. They found that in a three-row configuration the inlet temperature decreased by a maximum of $10.3^{\circ} \mathrm{C}$. This configuration also has an HPHE effectiveness value of between 47.9 and $54.4 \%$. The highest effectiveness value $(54.4 \%)$ was obtained at an inlet air velocity and temperature of $1 \mathrm{~m} / \mathrm{s}$ and $45^{\circ} \mathrm{C}$, respectively. The highest HPHE heat recovery value was $5,368 \mathrm{~W}$ at $2 \mathrm{~m} / \mathrm{s}$ inlet air velocity, giving a $51.7 \%$ HPHE effectiveness rating. 
We hope this special edition of IJTech provides useful information and knowledge, and we invite you to join us in this journal by sending your research for consideration.

With warmest regards from Jakarta,

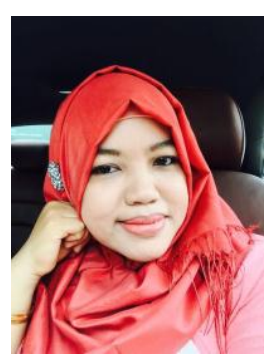

Dr. Eny Kusrini Editorial Board Member 